\title{
EVALUATION OF THE CUSTOMER SERVICE QUALITY WITH SERVQUAL METHOD IN THE CHOSEN COMPANY - PART I CUSTOMER PERSPECTIVE
}

\author{
Monika ODLANICKA-POCZOBUTT ${ }^{1 *}$, Arkadiusz SZMAL ${ }^{2}$ \\ ${ }^{1}$ Silesian University of Technology, Faculty of Organization and Management; \\ Monika.Odlanicka-Poczobutt@polsl.pl, ORCID: 0000-0001-7834-1188 \\ ${ }^{2}$ Silesian University of Technology, Faculty of Organization and Management; \\ arkadiusz.szmal@polsl.pl, ORCID: 0000-0001-6395-618X \\ * Correspondence author
}

Purpose: The aim of the paper is to present the usefulness of the Servqual method in improving the customer service quality in terms of identification of the deficiencies in the process of providing the service.

Design/methodology/approach: The Servqual method has been used in the research and it helped evaluating the level of customer expectations. The evaluation was based on separate criteria which allowed to examine how the perception of the service by customers is shaped. The unweighted $\left(S_{n}\right)$ and weighted $\left(S_{w}\right)$ servqual indicator was calculated for each of the examined dimensions. They were also interpreted.

Findings: The main result of the work was the diagnosis and the evaluation of the customer service quality in the chosen service company. Moreover, received results confirmed the high usefulness of the Servqual method for the management of the quality in terms of requirements of the customers.

Research limitations/implications: During the research and inference, it was noticed that the client's perspective, although prominent, should be extended by the perspective of the researched subject's personnel.

Practical implications: The presented approach finds practical application in the process of identification of the weaknesses of customer service and indicates factors of changes which can be used for improving the quality also in small enterprises. The method, on the one hand, is simple to use and its results offer clear indications for the people managing the company. The dissemination of its usage could significantly improve the situation, especially of the SME, which often cannot detect the expectations of the customers and cannot formulate the customer service strategy effectively.

Originality/value The paper confirms effectiveness of the Servqual method in evaluation of the customer service quality in small companies and allows to identify deficiencies in the service provision process.

Keywords: Servqual method, customer service level, quality.

Category of the paper: Research paper. 


\section{Introduction}

Everyday, business entities operating in the market economy undertake the challenges necessary to survive in a competitive market. Many business entities struggle with correct detection of the customers expectations and with recognising in time the change creating factors in this area (Cronin\&Taylor, 1992). Enterprises look for various forms of innovation activities which will allow them to adapt to new market challenges (Szmal, 2015). Particularly, in the group of small and medium enterprises, there is a deficit of tools allowing to effectively formulate directions for improving the quality of the customer service.

Areas of problems occurring in the entities providing the services result from their characteristics. Especially important matter is the mutual interaction which influences client's subjective opinion on the service. Low quality of the provided service may cause outflow of the customers, whereas high quality will be an appropriate encouragement for potential customers. All the emerging problems in service companies affect the perception of current and potential customers, along with the market competition. Literature provides a lot of inspiration in searching for methods to improve the quality of services (Prentkovskis, Erceg, Stević, Tanackov, Vasiljević, Gavranović, 2018), (Pekkaya, İmamoğlu, Koca, 2019).

The concept of customer service is one of the most important elements of the enterprise strategy. Customer service and logistic customer service (Kramarz, 2014) include all areas of contact between the supplier and the purchaser and bonds intangible and tangible elements. It significantly affects the level of relationships and loyalty of the customer which can be classified as the most valuable assets of any company. Long-term relationships are the foundation of higher profitability of the enterprise, while identification of the disruptions in the order cycle allows for quick reaction and provides an opportunity for improvement of the service level when it is still possible (Odlanicka-Poczobutt, Kulińska, 2017). To gain and retain the customer it is necessary to understand what the value means to him. Interesting papers on the microeconomic concept of flexibility to assess this flexibility of the Servqual gap in order to obtain important information for service providers to develop appropriate strategies in service provision can also be found in the literature. (Kumar, Sujit, Charles. 2018). Recently, the creation of customer service centers has also become increasingly important. (Lotko, 2003, 2004, 2009). The example of the Servqual method presented in the paper focuses on these processes which allow to deliver this value while continuously improving customer service on each of its stage. The identified research gap is based on the statement that companies do not always use the Servgual method to determine the difference between the perceived and expected level of service quality, but only to determine the current level signaled by the customer. An attempt to fill this gap is to undertake research from two perspectives - the client and the personnel of the examined company. 
The aim of the paper is to present the usefulness of the Servqual method in improving the customer service quality in terms of identification of the deficiencies in the process of providing the service. The scope of the paper comprise of the review of the literature in terms of the attributes of the Servqual method and its practical use. Empirical research was conducted with 119 customers of the chosen entity. In the paper the results of the first part of the research were presented - evaluation of the customer service quality from the perspective of the customer. Further research (perspective of the personnel of the studied entity) will be presented in the next paper.

\section{Servqual method - key attributes}

Paper size: Servqual research method was developed by A. Parasurman, L. Berry and V.A. Zeithaml (Berry, Parasuraman, Zeithaml, 1990) and it is used for evaluation of the customers expectations level (Bielawa, 2010). The evaluation is based on separated criteria by which it is examined how the service is perceived and how the expectations of the customer are fulfilled by the contractor. These criteria consist of:

- tangibles,

- reliability,

- responsiveness,

- assurance,

- empathy.

The Servqual method is based on a survey questionnaire that consists of two sections. Each of them includes a set of statements based on the above criteria. Their number depends on the level of detail of the conducted research and it oscillates between 5 and 29 where the level of detail is high. The first section consists of statements concerning the evaluation of expectations about the service, the second section about the service received. Interviewees evaluate each statement using Likert scale. The difference between perception of the service and its desired level allows to assess the perceived quality of the service (Stasiak-Betlejewska, Borkowski, 2010). The bigger the difference, the bigger the dissatisfaction of the consumer caused by insufficient fulfilment of particular expectations. Authors of the Servqual method emphasised that the service companies should evaluate its usefulness and possibly verify the set of analysed statements by themselves.

Because of its universal character, the Servqual method can be used for objective evaluation of perceived quality in all kinds of services. The literature indicates the potential of the method in this field. (Ladhari, 2009). Improving service quality with information technology is also gaining importance (Berkley, \& Gupta, 1994; Broderick,\& Vachirapornpuk, 2002; Santos, 2003). By dividing the service on five elements - Servqual criteria, it is possible to locate the 
deficiencies in the process of providing the service which often deter customers. The interest of enterprises in this method of studying the perception of quality allows to improve the quality and thus to achieve competitiveness. However, it mostly allows to achieve the satisfaction of the customer (Wolniak, Kostorz, 2004).

The Servqual method creates a basic system of expectations and perception which includes references to each of the five service-quality dimensions i.e. tangibles, reliability, assurance, responsiveness and empathy. Relying on the Servqual method, the company can determine if its service fulfils the customer expectations by asking the same questions concerning the requirements for the service before its realisation and then after receiving it. Confrontation of the results indicates which areas should be improved and this is the essence of evaluating the quality of the provided service (Pacana, 2011).

The aim of the Servqual method is to measure expectations of the customers, so-called expected quality, and perception of the service quality, so-called perceived quality. The measurement is conducted using the questionnaire consisting of specific statements which are the expansions of earlier mentioned five criteria groups. For measurement, the Likert scale is used, the essence of which is the respondent's evaluation of the degree of compliance between their views and the statements included in the questionnaire, related to the quality of services.

The expected quality is measured on the basis of the interviewee's ideas about such service company that they would like to use. Measurement of the quality of the provided services is based on the respondent's experiences resulting from using these services, or on the basis of their ideas about such services. The same statements evaluating the quality of service are used for the assessment of both expected and perceived quality. Because of that, it is possible to calculate the deficiency as the difference between the average assessment for each statement referring to the expected and perceived quality (Dyr, 2006).

The SERVQUAL method is often expressed by the following method:

$\mathrm{S}=\Sigma(\mathrm{P}-\mathrm{O})$

where:

$\mathrm{S}$ - the degree of meeting consumers expectations (the result of the Servqual method),

$\mathrm{O}$ - expected quality of service,

P - perceived quality of service (Goranczewski, Puchato 2011),

where:

$\mathbf{P}=\mathbf{O}$ desired state: customers are fully satisfied with the service,

$\mathbf{P}>\mathbf{O}$ ideal state: customers perception of the service exceeds significantly their expectations, $\mathbf{P}<\mathbf{O}$ conditional state: customers expectations about the service has not been quite fulfilled.

While using the Servqual method, the importance of each quality criteria for the customer is also evaluated. A rank scale of summed grades is used for this evaluation. Its essence is to divide 100 points between mentioned characteristics, depending on the relevance to the respondent. This allows to use these criteria as weight functions while calculating the synthetic quality indicator. 


\section{Measurement and evaluation of the quality of service using the Servqual method}

The research was conducted in real conditions in the service company and it provided a basis for evaluation of the services offered by the company. While developing information gathered during the research, according to the procedure which included: evaluation of the expectations $(\mathrm{O})$, evaluation of the observations $(\mathrm{S})$, determining the difference between the perceived and expected level, calculating total substantive measure of the quality of service, determining importance of each dimension, calculating Servqual weighted average and total weighted measure of the quality of service. The unweighted servqual indicator was calculated first and the weighted Servqual indicator was calculated afterwards. The collected data was processed using the spreadsheet. The results obtained among the customers of the company were presented first.

Quality determinants developed by V. Zeithaml, A. Parasuraman and L. Berry constituted the basis for determining and defining the quality parameters for services being the subject of ongoing research. Twenty three detailed indicators (dimensions) for evaluating the quality of services have been defined for the five individual quality dimensions (Bielawa, 2011):

1. Tangibles of the service:

- visual attractiveness of the building and the interior,

- flexibility in the selection of the payment method,

- neat appearance of the employees,

- modern equipment, completeness of advertising materials,

- wide range of the products,

- competitive price.

2. Reliability of the service:

- keeping the conditions of the realised sale,

- convenience in communication,

- correctness of performed service,

- reliability and comprehensiveness of services,

- flawless documentation.

3. Responsibility for the realisation of the service:

- information about the date of service,

- prompt realisation of the service,

- professional help of the personnel,

- employee response to the customer needs. 
4. Assured realisation of the service:

- trust and safety,

- accessibility of the service,

- opening hours,

- knowledge and level of personnel qualifications.

5. Empathy while providing the service:

- individual approach,

- courtesy and kindness,

- loyalty programme for regular customers,

- understanding the needs of the customer.

The paper presents research devoted to the evaluation of the quality of services of the examined entity made from the point of view of the customers. The research was conducted with 119 customers of the studied entity. The survey method with the technique of direct interview using the questionnaire developed for this purpose was used. For the analysis of data, 105 correctly completed surveys was accepted.

Among the respondents, $50.48 \%$ of the surveyed customers were women and $49.52 \%$ men. Most of the respondents were between 26 and 40 years old $-40 \%$, then between 40 and 60 years old $-26.67 \%, 19-25$ years old $-21.9 \%, 61$ years old and older $-7.62 \%$, up to 18 years old $-3.81 \%$. Secondary education dominated among the respondents $-41.9 \%$, higher education $-30.48 \%$, vocational education $-22.86 \%$, primary education $-4.76 \%$. The subject of the study was the evaluation of customers satisfaction from the quality of services provided by the examined entity. The unweighted result of the Servqual method $\left(\mathrm{SQ}_{\mathrm{n}}\right)$ among the customers is presented in the Tab. 1.

Table 1.

Arithmetic difference of observations and expectations regarding the quality of service defined by the customers

\begin{tabular}{|l|l|l|c|c|c|}
\hline \multicolumn{5}{|c|}{ Expectations and perceptions concerning the quality of service - arithmetic measures } \\
\hline \multicolumn{2}{|c|}{ Quality criteria } & $\begin{array}{c}\text { Customers } \\
\text { expectations }\end{array}$ & $\begin{array}{c}\text { Customers } \\
\text { perceptions }\end{array}$ & $\begin{array}{c}\text { Arithmetic } \\
\text { difference }\end{array}$ \\
\hline 1 & tangibles & $\begin{array}{l}\text { Visual attractiveness of the building } \\
\text { and the interior }\end{array}$ & 4,12 & 4,46 & 0,33 \\
\hline 2 & tangibles & $\begin{array}{l}\text { Flexibility in the selection of the } \\
\text { payment method }\end{array}$ & 4,42 & 4,22 & $-0,20$ \\
\hline 3 & tangibles & Neat appearance of the employees & 4,19 & 4,50 & 0,30 \\
\hline 4 & tangibles & $\begin{array}{l}\text { Modern equipment, completeness of } \\
\text { advertising materials }\end{array}$ & 4,22 & 4,23 & 0,01 \\
\hline 5 & tangibles & Wide range of the products & 4,53 & 4,43 & $-0,10$ \\
\hline 6 & tangibles & Competitive price & 4,64 & 4,44 & $-0,20$ \\
\hline
\end{tabular}


Cont. table 1.

\begin{tabular}{|l|l|l|c|c|c|}
\hline 7 & reliability & $\begin{array}{l}\text { Keeping the conditions of the realised } \\
\text { sale }\end{array}$ & 4,65 & 4,48 & $-0,17$ \\
\hline 8 & reliability & Convenience in communication & 4,08 & 4,03 & $-0,05$ \\
\hline 9 & reliability & Correctness of performed service & 4,32 & 4,41 & 0,09 \\
\hline 10 & reliability & $\begin{array}{l}\text { Reliability and comprehensiveness of } \\
\text { services }\end{array}$ & 4,58 & 4,30 & $-0,28$ \\
\hline 11 & reliability & Flawless documentation & 4,23 & 4,20 & $-0,03$ \\
\hline 12 & responsiveness & $\begin{array}{l}\text { Information about the date of the } \\
\text { service }\end{array}$ & 4,36 & 4,28 & $-0,09$ \\
\hline 13 & responsiveness & Prompt realisation of the service & 4,48 & 4,31 & $-0,16$ \\
\hline 14 & responsiveness & Professional staff help & 4,31 & 4,29 & $-0,03$ \\
\hline 15 & responsiveness & $\begin{array}{l}\text { Employee response to the customer } \\
\text { needs }\end{array}$ & 4,49 & 4,39 & $-0,10$ \\
\hline 16 & assurance & Trust and safety & 4,43 & 4,42 & $-0,01$ \\
\hline 17 & assurance & Accessibility of the service & 4,36 & 4,04 & $-0,32$ \\
\hline 18 & assurance & Opening hours & 4,38 & 4,47 & 0,09 \\
\hline 19 & assurance & $\begin{array}{l}\text { Knowledge and level of personnel } \\
\text { qualifications }\end{array}$ & 4,58 & 4,40 & $-0,18$ \\
\hline 20 & empathy & Individual approach & 4,43 & 4,28 & $-0,15$ \\
\hline 21 & empathy & Courtesy and kindness & 4,50 & 4,57 & 0,08 \\
\hline 22 & empathy & $\begin{array}{l}\text { Loyalty programme for regular } \\
\text { customers }\end{array}$ & 3,89 & 3,55 & $-0,33$ \\
\hline 23 & empathy & $\begin{array}{l}\text { Understanding the needs of the } \\
\text { customer }\end{array}$ & 4,20 & 4,23 & 0,03 \\
\hline
\end{tabular}

The initial analysis of the servqual tool survey for the customer community showed the results describing general expectations and observations of the customers after the purchase of service and product offered by the examined entity. Tab. 1 includes comparison of differences between observations and expectations of individual customers.

The consumers assessed negatively 16 particular theses out of 23 included in the survey. After assigning the importance to individual dimensions, 4 out of 5 possible were rated negatively.

\section{Table 2.}

The importance of quality dimensions in customers opinion

\begin{tabular}{|l|c|c|c|c|c|}
\hline \multirow{2}{*}{} & \multicolumn{5}{|c|}{ Quality dimensions } \\
\cline { 2 - 6 } & tangibles & reliability & responsibility & assurance & empathy \\
\hline $\begin{array}{l}\text { The importance } \\
\text { of dimension }\end{array}$ & 20.86 & 19.62 & 20.91 & 20.08 & 18.53 \\
\hline
\end{tabular}

The analysis of the importance of each criteria showed in table 2 that the most important dimension for the customers is "responsibility" (dimension 3), then "tangibles" (dimension 1) and "assurance" (dimension 4). Customers found "empathy" (dimension 5) and "reliability" (dimension 2) the least significant, but also important.

In the order (from the lowest rated criterion to the best rated), examined quality characteristics provided by the store employees according to the opinions of its customers are as follows - Table 3: 
Table 3.

Ascending order of quality dimensions according to the groups of criteria

\begin{tabular}{|c|c|c|}
\hline & Ascending order of quality dimensions & Group of dimension criteria \\
\hline 1 & Loyalty programme for regular customers -0.33 . & empathy \\
\hline 2 & Accessibility of the service & assurance \\
\hline 3 & Reliability and comprehensiveness of services & reliability \\
\hline 4 & Flexibility in the selection of the payment method & tangibles \\
\hline 5 & Competitive price & tangibles \\
\hline 6 & Knowledge and level of personnel qualifications & assurance \\
\hline 7 & Keeping the conditions of the realised sale & reliability \\
\hline 8 & Prompt realisation of the service & responsiveness \\
\hline 9 & Individual approach & empathy \\
\hline 10 & Wide range of the products & tangibles \\
\hline 11 & Employee response to customer needs & responsiveness \\
\hline 12 & Information about the date of the service & responsiveness \\
\hline 13 & Convenience in communication & reliability \\
\hline 14 & Flawless documentation & reliability \\
\hline 15 & Professional staff help & tangibles \\
\hline 16 & Trust and safety & assurance \\
\hline 17 & Modern equipment, completeness of advertising materials & responsiveness \\
\hline 18 & Understanding the needs of the customer & empathy \\
\hline 19 & Courtesy and kindness & empathy \\
\hline 20 & Opening hours & assurance \\
\hline 21 & Correctness of performed service & reliability \\
\hline 22 & Neat appearance of the employees & tangibles \\
\hline 23 & Visual attractiveness of the building and the interior $(0,33)$ & tangibles \\
\hline
\end{tabular}

The given order shows which deficiencies of the criteria among specific quality dimensions should be eliminated first. Most of the values are negative as the result of the adopted initial values. Indicators defining the arithmetic value within 0.00 point mean the right standard of the service quality, i.e. such for which the customer is willing to pay. Three positions such as: „loyalty programme for regular customers” (-0.33), „accessibility of the service” (-0.32), „reliability and comprehensiveness of services” (-0.28) are found by the customers as below standard and differ significantly from their expectations.

Data adjusted by determining the dimensions validity by the consumers (Table 2) is shown in Table 4. The table presents a weighted rating that results from taking into account consumer expectations and perceptions regarding the quality of services assigned to the weights for individual criteria. 
Table 4.

Arithmetic difference, weighted difference and importance of quality dimensions in the opinion of customers

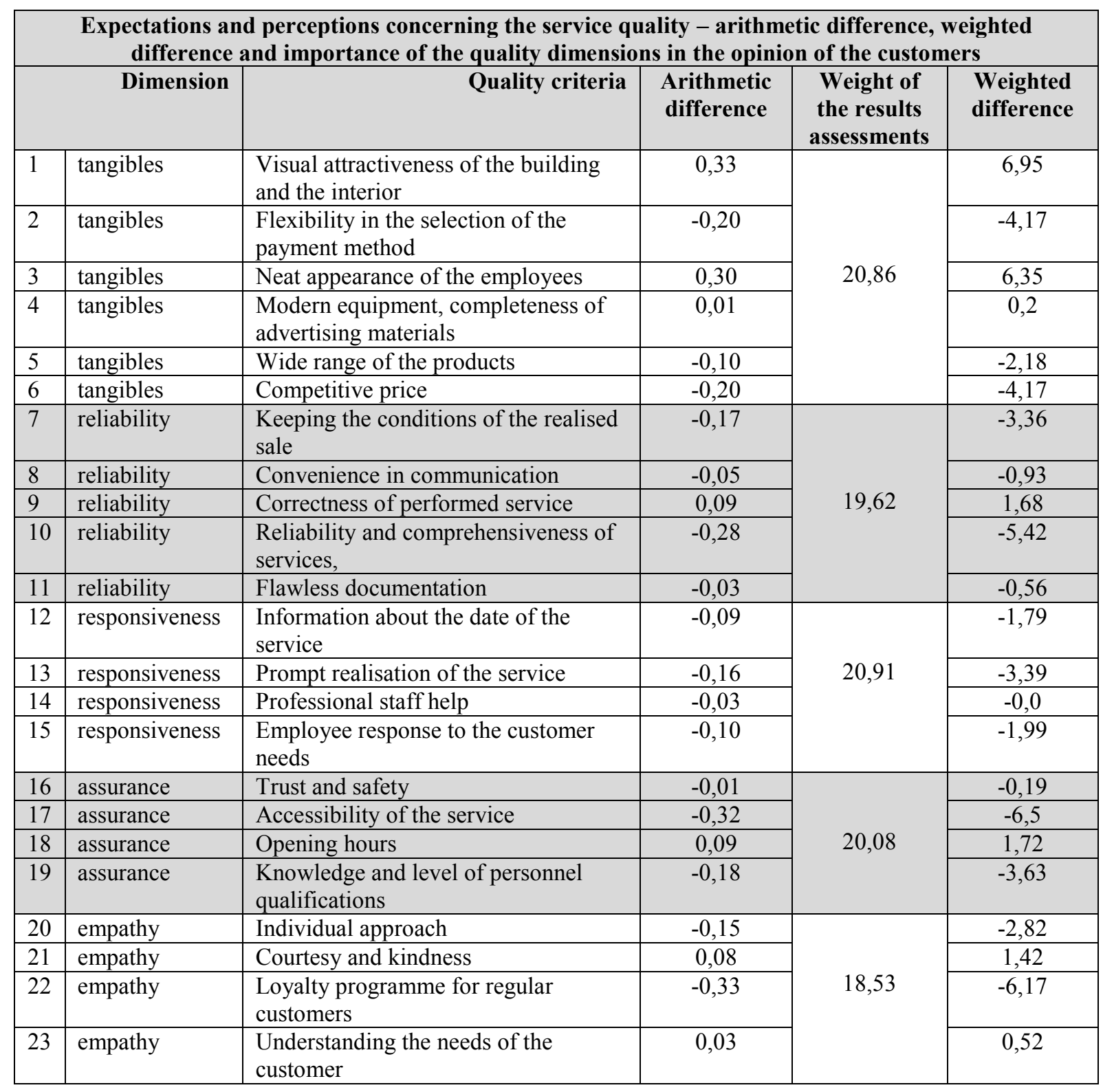

Obtained results (Table 4) show the evaluation of the service quality provided by the examined entity as an average correlated with importance of the criteria indicated by the customers. There are significant changes of the initial (arithmetic) values in proportion to the changes of the weighted values. The obtained results show that in comparison to the values defined as arithmetic average (Table 1), the dimensions the value of which was defined as weighted difference (Table 4), were subjected to slight but important revaluation and thus, the criteria which have the biggest influence on the customer satisfaction have changed. 
Table 5.

Ascending order of weighted quality dimensions according to the groups of criteria

\begin{tabular}{|c|c|c|}
\hline & Ascending order of quality dimensions & Group of dimension criteria \\
\hline 1 & Accessibility of the service $(-6.5)$ & assurance \\
\hline 2 & Loyalty programme for regular customers -0.33 . & empathy \\
\hline 3 & Reliability and comprehensiveness of services & reliability \\
\hline 4 & Flexibility in the selection of the payment method & tangibles \\
\hline 5 & Competitive price & tangibles \\
\hline 6 & Knowledge and level of personnel qualifications & assurance \\
\hline 7 & Prompt realisation of the service & responsiveness \\
\hline 8 & Keeping the conditions of the realised sale & reliability \\
\hline 9 & Individual approach & empathy \\
\hline 10 & Wide range of the products & tangibles \\
\hline 11 & Employee response to customer needs & responsiveness \\
\hline 12 & Information about the date of the service & responsiveness \\
\hline 13 & Convenience in communication & reliability \\
\hline 14 & Professional staff help & responsiveness \\
\hline 15 & Flawless documentation & reliability \\
\hline 16 & Trust and safety & assurance \\
\hline 17 & Modern equipment, completeness of advertising materials & tangibles \\
\hline 18 & Understanding the needs of the customer & empathy \\
\hline 19 & Courtesy and kindness & empathy \\
\hline 20 & Correctness of performed service & reliability \\
\hline 21 & Opening hours & assurance \\
\hline 22 & Neat appearance of the employees & tangibles \\
\hline 23 & Visual attractiveness of the building and the interior (6.95) & tangibles \\
\hline
\end{tabular}

When it comes to the indicators that define weighted value of the criteria, they vary between -6.5 and 6.95 points. Apparent variance is quite significant. Average arithmetic difference and average weighted difference are the basis for calculating the indicators of the unweighted $\left(\mathrm{SQ}_{\mathrm{n}}\right)$ and weighted $\left(\mathrm{SQ}_{\mathrm{w}}\right)$ servqual for each defined quality dimension (Tab.6). The obtained general indicators $\left(\mathrm{SQ}_{\mathrm{n}}\right)$ and $\left(\mathrm{SQ}_{\mathrm{w}}\right)$ have shown that most of 23 evaluated quality criteria (exactly 16 of them), defined for the service of the examined entity, is negative in the opinion of the customers. And here, after assigning the individual criteria weights from their dimension, as in the values of arithmetic parameters, the worst came off: „loyalty programme for regular customers" $(-6.17)$, ,accessibility of the service” (-6.5), „reliability and comprehensiveness of services” $(-5.42)$. We can spot the difference that by assigning the importance to the criteria, the biggest influence on satisfaction have first of all ,accessibility of the service”, then „loyalty programme for regular customers” and then „reliability and comprehensiveness of services” which did not change its position. 
Table 6.

Unweighted and weighted servqual indicator for each of the quality dimension in the opinion of the customer

\begin{tabular}{|l|c|c|}
\hline \multicolumn{2}{|c|}{ Unweighted SQ (SQnw) and weighted SQ (SQw) for each of the consumers dimensions } \\
\hline Dimension & SQ nw & SQ w \\
\hline Dimension 1: tangibles & 0.024 & 0.4967 \\
\hline Dimension 2: reliability & -0.088 & -1.719 \\
\hline Dimension 3: responsiveness & -0.093 & -1.942 \\
\hline Dimension 4: assurance & -0.107 & -2.151 \\
\hline Dimension 5: empathy & -0.095 & -1.765 \\
\hline & -0.07 & -1.42 \\
\hline
\end{tabular}

As a consequence of the quality of service evaluation made by consumers, the following indicators have been determined: unweighted $\left(\mathrm{SQ}_{\mathrm{n} 1} \ldots \mathrm{SQ}_{\mathrm{n} 22}\right)$ and weighted $\left(\mathrm{SQ}_{\mathrm{w} 1} \ldots \mathrm{SQ}_{\mathrm{w} 22}\right)$ for each of the quality criteria (tab.1), unweighted $\left(\mathrm{SQ}_{\mathrm{n} 1} \ldots \mathrm{SQ} \mathrm{Q}_{\mathrm{n} 5}\right)$ and weighted $\left(\mathrm{SQ}_{\mathrm{w} 1} \ldots \mathrm{SQ} \mathrm{w}_{\mathrm{w}}\right)$ for the quality dimensions (tab.4). The $\mathrm{SQ}_{\mathrm{nw}}$ indicator is calculated by arithmetic average of a difference of expectations and perceptions of individual criteria creating dimensions. Afterwards, when the comparison of weighted values for dimensions is calculated, the $\mathrm{SQ}_{\mathrm{ww}}$ is calculated as the value of arithmetic average of a weighted difference.

The obtained results show that purchasing the service in 4 out of 5 evaluated dimensions is not satisfying in terms of quality in the opinion of the consumers. Most negatively the customers rated the fourth dimension: ,assurance". In terms of importance this dimension is also on the first place. After the "assurance" which in both cases was rated as the lowest, the dimensions, after assigning the importance to them, were ranked successively as the lowest rated: „responsibility”, „empathy”, „reliability”. Only "tangibles" gained positive rating and according to the customers does not deviate from their requirements and expectations. Therefore, considering opinion of the customers, the service provider should start acting correctively and proactively, to begin with the ,,assurance” dimension.

Most of the evaluated criteria were assessed negatively by the customers. The obtained results indicate the necessity for improvement of the $70 \%$ of analysed criteria which influence the creating of the quality level and satisfaction from the services provided by the examined entity. This results from variances between customers expectations and perceptions in terms of the quality of received services.

The obtained research results among the clients are concerning. As a result of using the Servqual method for measurement and analysis, the obtained synthetic quality measures, which are defined as the servqual result (SQ), are negative. It concerns both general results and a partial dimension of quality. Both unweighted $\left(\mathrm{SQ}_{\mathrm{nw}}\right)$ and weighted $\left(\mathrm{SQ}_{\mathrm{w}}\right)$ servqual results are negative. The weighted servqual result is definitely lower, which means that the qualities of the offered service most important for the clients were rated more negatively. Whereas, the difference between these two results indicates the necessity for improvement of the perceived service quality. 


\section{Conclusion}

The Servqual method of measuring the quality of services allows not only to estimate the overall quality of services, but also to identify deficiencies in the process of providing services. The analysis of the results is conducted on the basis of the quantitative and qualitative research results with questionnaires created for this purpose. The questionnaires were conducted among clients and employees of the examined entity.

The customers rated the offered quality of services on the level of -0.07 point (unweighted result) and by assigning weight to the specific criteria of service, the assessment has changed and totalled: -1.42 points (weighted result). This means that the requirements and needs of the customers are not fully satisfied by the store, however, the difference between the expected and received quality is not that significant. Still, in the long run, such permanent state of lack of improvement may cause frustration among the customers and may become the reason for them to leave to the competition if only it offers better conditions.

Considering the obtained results, it may be stated that the owner of the company in the process of improving the quality of services should focus primarily on the following examined criteria among the customers: „loyalty programme”, ,accessibility of service”, „reliability and comprehensiveness of services". These factors influencing the quality of service were rated negatively by the customers. They also had the worst results in further calculations including their importance obtained by assigning weights to the specific dimensions. Interestingly, by assigning the importance, the ,accessibility of service" criterion obtained lower rating in relation to the "loyalty programme" criterion which in arithmetic calculations obtained the lowest rating. In the customers opinion, the business owner should develop new programme which will reduce the waiting time for the service. What might be helpful is the implementation of the quality system that focuses on communication between the customer and employee. The reduction of the employee turnover would be an important element requiring correction, by which the customer will receive the sense of permanency, security and understanding from the store personnel. Analysing the ,accessibility of service” criterion, which by assigning the weight is the most urgent to improve, the owner should examine the possibility of hiring extra employee and opening another customer service point in order to decrease the waiting time for the service. Criterion from the marketing point of view speaking of the loyalty programme in the store was indicated as the second in terms of the importance for the client. At the moment, the loyalty programme is available only to the customers using a very small part of the stock. With this group in mind, a loyalty card was created that allows for $10 \%$ discount. The owner of the business could extend the range of products sold with the loyalty card. He/she might as well join the group of entrepreneurs creating one common card which enables the possibility of discounted purchase in many places of the network members. The customers are very satisfied with the visual attractiveness of the building and the interior. The criterion concerning visual 
attractiveness obtained the highest rating with the entire dimension in which it was placed. Researched quality dimension: „tangibles of the service” obtained positive servqual result which means that the owner has excessively committed funds for the visual elements. Thanks to this information, the owner of the business can use part of the funds intended for visualization for the improvement of the criteria which obtained negative servqual result.

The applied approach offers many valuable managing guidelines, however, an appropriate complement is the perspective of the personnel, thus the authors of the paper will conduct the research also in this perspective. This will be presented in the article,,Evaluation of the customer service quality with Servqual method in the chosen service company - part II personnel perspective".

\section{References}

1. Berkley, B., Gupta, A. (1994). Improving service quality with information technology. International Journal of Information Management, 14.

2. Berry, L., Parasuraman A., Zeithaml V. (1990). Delivering Quality Service. Balancing, Customer Perceptions and Expectations. New York: Free Press, p. 25.

3. Bielawa, A. (2010). Przegląd najważniejszych modeli zarządzania jakością usług. Studia i Prace Wydziału Nauk Ekonomicznych i Zarzadzania, 24.

4. Bielawa, A. (2011). Przegląd najważniejszych modeli zarządzania jakością usług. Studia i prace Wydziału Nauk Ekonomicznych i Zarzadzania, nr 24. Uniwersytet Szczeciński, WNEiZ.

5. Broderick, A., Vachirapornpuk, S. (2002). Service quality in internet banking: the importance of customer role. Marketing Intelligence \& Planning, 20(6).

6. Cronin, J., Taylor, S. (1992). Measuring Service Quality - a Reexamination and Extension. Journal of Marketing, 56(3).

7. Dyr, T. (2006). Wykorzystanie metody servqual w ocenie jakości kolejowych przewozów regionalnych. Problemy Kolejnictwa, pp. 116-129.

8. Goranczewsk, B., Puciato, D. (2011). Application of SERVQUAL Questionnaire in the Measurement of Quality of Hotel Services. Polish Journal of Sport and Tourism, No. 18, pp. 166-171.

9. Kramarz, M. (2014). Elementy logistyczne obstugi klienta w sieciach dystrybucji. Pomiar, ocena, strategie. Warszawa: Wydawnictwo Difin.

10. Kumar, M., Sujit, K.S., Charles, V. (2018). Deriving managerial implications through SERVQUAL gap elasticity in UAE banking. International Journal of Quality \& Reliability Management, Vol. 35 No. 4, pp. 940-964. https://doi.org/10.1108/IJQRM-10-2016-0176. 
11. Ladhari, R. (2009). A review of twenty years of SERVQUAL research. International Journal of Quality and Service Sciences, Vol. 1 No. 2, pp. 172-198. https://doi.org/ 10.1108/17566690910971445.

12. Lotko, A. (2003). Zarzadzanie relacjami z klientem. Strategie $i$ systemy. Radom: Wydawnictwo Politechniki Radomskiej.

13. Lotko, A. (2004). Call Center as a Perspective Form of Improving Customer Service Quality. Regionalna Ekonomika, 2.

14. Lotko, A. (2009). Ocena jakości usług w centrach kontaktu z klientem. Warszawa: PWN.

15. Odlanicka-Poczobutt, M., Kulińska, E. (2017). Identyfikacja zakłóceń w cyklu realizacji zamówienia w wybranym przedsiębiorstwie handlowym. Zeszyty Naukowe Politechniki Śląskiej, Seria Organizacja i Zarządzanie, z. 107, pp. 69-86.

16. Pacana, A., Sęp, J., Zielecki, W. (2011). Ocena jakości usług dydaktycznych na przykładzie studiów podyplomowych. Czasopismo Komputerowo zintegrowane zarzadzanie. Opole: Oficyna Wydawnicza Polskiego Towarzystwa Zarządzania Produkcją.

17. Pekkaya, M., İmamoğlu Ö.P., Koca H. (2019) Evaluation of healthcare service quality via Servqual scale: An application on a hospital, International Journal of Healthcare Management, 12, 4, 340-347, DOI: 10.1080/20479700.2017.1389474.

18. Prentkovskis, O., Erceg, Ž., Stević, Ž., Tanackov, I., Vasiljević, M., Gavranović, M.A. (2018). New Methodology for Improving Service Quality Measurement: Delphi-FUCOMSERVQUAL Model. Symmetry, 10, 757.

19. Santos, J. (2003). E-service quality: a model of virtual service quality dimensions. Managing Service Quality, 13(3).

20. Stasiak-Betlejewska, R., Borkowski S. (2010). Identyfikacja poziomu satysfakcji klienta banku w procesie usługowym przy wykorzystaniu metody Servqual. Zeszyty Naukowe, Polityki Europejskie, Finanse i Marketing, Nr 3(52), p. 74.

21. Szmal, A. (2015). The role of innovative initiatives in innovative activities in the enterprise. 2nd International Multidisciplinary Scientific Conference on Social Sciences and Arts. SGEM 2015, In: Book 2. Political sciences, law, finance, economics and tourism, Vol. 3, Economics and tourism. Sofia: STEF92 Technology, pp. 915-922.

22. Urbaniak, A.M. (2013). Zastosowanie metody SERVQUAL do oceny jakości usług rekreacyjnych. Zeszyty Naukowe Uczelni Vistula, 32, pp. 29-38.

23. Wolniak, R., Kostorz, E. (2004). Wykorzystanie metody Servqual do badania jakości usług świadczony przez stacje benzynowe. Problemy jakości, $n r$ 12, pp. 41-46. 